\title{
US research budget now in better shape
}

\section{Dying Congress restores earlier cut-backs}

\section{Washington}

It may not last, but in contrast with previous years, when President Carter's requests for additional funding for science were trimmed back by Congress, the final 1981 research budget looks in even better shape than when it was presented in January 1980.

The Administration revised its initial request in March, reducing a proposed growth in spending on research and development from 11 to 8 per cent. But while Congress has agreed to cuts in other areas of social spending, research and development has been relatively protected.

Last week, for example, when Congress finally agreed to an appropriations bill covering the budgets for 23 assorted federal agencies, only three - the National Aeronautics and Space Administration (NASA), the National Science Foundation (NSF), and the American Battle Monuments Division - received more money than they had asked for.

As in previous years, legislators have been kind to the budget of the National Institutes of Health (NIH). Although the final figure is yet to be agreed, the House has approved an NIH budget of $\$ 3,616$ million, and last week the Senate gave its approval to a $\$ 3,686$ million budget. Whichever figure is finally decided upon, it will be higher than the $\$ 3,581$ million initially requested, and will result in a 5.5 to 7.5 per cent increase in NIH's budget over - last year.

In the Department of Energy, threats to the basic research budget - which includes funding for high-energy physics and nuclear physics - were successfully fought off during the summer. The final sum for items under the responsibility of the department's Office of Energy Research will be $\$ 1,145$ million, only slightly less than the $\$ 1,203$ million requested, with the major reduction being the postponement of improvements to facilities at the national research laboratories.

Only in the case of the Department of Defense, for which the Administration had originally requested a hefty 17 per cent increase in spending on basic research, is the final figure likely to be substantially lower. Congress has approved an appropriations bill which will cut this increase to 12.5 per cent, reducing the planned real increase from 8 to 3.5 per cent. The final figure may be even less, since Congress has also asked the Pentagon to impose further unspecified cuts totalling 4 per cent across the whole of its research and development budget. In the case of NASA and NSF as well, the final figures may be reduced by a requirement that the Office of Management and Budget distributes a further 2 per cent cut across all the agencies covered in the appropriations bill.

Congress has also forced several significant changes in the content of the Administrations proposals for federallysponsored research programmes.

At NSF, for example, sustained pressure from Senator Edward Kennedy has led to the agreement to introduce a new programme to boost women and minority scientists. Mr Kennedy had added his own "Women in Science" bill to the Senate version of the NSF appropriations bill; and the House finally agreed to a $\$ 30$ million programme which will include more than 100 grants for women scientists extra to those which would be otherwise awarded. The NIH budget, on which a final total has yet to be settled, includes an extra $\$ 35$ million for training grants which the Administration had suggested be cut back to enable the number of new and competing research grant awards to be kept constant.

A large part of the increase in NASA's budget will go to cover the additional costs of the much-delayed space shuttle. However, Congress is also becoming increasingly concerned about cost and schedule over-runs in virtually all of the space science programmes.

As a result, Congress has directed NASA to ensure that it receives approval from the National Academy of Sciences before making any substantial programme changes. This move, opposed by several NASA administrators, is supported by Congress as a way of ensuring an adequate response to any future technical difficulties.

Despite the set-backs being experienced by the various space science programmes, almost all have escaped the congressional budget process relatively unscathed, including the proposed new gamma-ray observatory. However, there were warnings that some projects could still be halted through budget rescissions early next year when the new administration takes over.

\section{Oil, shale or mirage in West Siberia?}

The strange story of the supposed Bazhenov oil field in western Siberia, with its reserves of over 600,000 million tonnes of oil, reached the world's newspapers two weeks ago at a particularly sensitive moment. The threat to world oil supplies posed by the Gulf War, and Western contingency plans for a further technological embargo on the Soviet Union should Soviet troops be ordered into Poland, and the impending OPEC meeting in Bali made the announcement of the new field, with reserves surpassing world proved oil reserves, a major consideration for politicians and oil magnates alike.

The report on the Bazhenov field came from Petrostudies, a two-man Swedish team which monitors all open Soviet publications on the oil industry. The consensus of expert opinion, ranging from the CIA to the Soviet oil industry, is that its report is an exaggeration. One French expert went as far as saying that it would amount to a "geological miracle"'. Petrostudies, however, remains adamant about the size of the find, but is now prepared to concede that a considerable proportion of the oil may not be recoverable.

Challenged with a Soviet statement that the deposit was not oil but shale, Petrostudies director Manlyo Jermol replied that the Bazhenov shale was scientifically important because it contained liquid crudc. Until now, he said, it had been believed that such oil was to be found only in porous rocks. He cited the Soviet geologist, Ivan Nesterov, director of the West Siberian Research Centre for Oil Prospecting who, in 1978, had announced that Soviet research had refuted the old text-book assertion that shales cannot accumulate free oil.

A few days before the Petrostudies announcement, Nesterov was interviewed on Moscow radio in connection with the publication of the guidelines for the new Five Year Plan. On this occasion he was vague about the West Siberian potential. The fields now in production yield more than 300 million tonnes of oil and gas condensate per year, he said - amounting to about half the total Soviet output. But since two thirds of all the fields discovered in the area have not yet been touched, and only one fifth of the oil-bearing region of West Sibcria has been explored it is difficult to make reliable estimates of the reserves. Extraction costs, he pointed out, are soaring, the costs of erecting a rig have risen 30 per cent in the last five years, and it has proved impossible to sustain the original growth rate. While maintaining that Western talk about Soviet oil running out in the near future is "highly premature", Nesterov's talk was couched in cautious terms. During the next five years, he said, the Soviet Union will be able to meet its own requirements and its committments to its trading partners. For the longer term, he gave no hint of any bonanza - shale or otherwise, of the type suggested by Petrostudies. Vera Rich 
The one potential casualty, the National Oceanic Satellite System (NOSS) - the proposed successor to the SEASAT satellite - will receive an extra \$6.4 million through the research budget of the Department of Commerce's National Oceanic and Atmospheric Administration (NOAA). NOAA has also received an additional $\$ 1$ million for manned undersea facilities, but had $\$ 2$ million for acid rain research cut from its budget.

In biomedical research, Congress has rejected proposals from both the House and the Senate for greater supervision of NIH. A bill continuing authorization for the National Cancer Institute and the National Heart, Lung and Blood Institute was passed on 5 December without either the provision for a Presidential Commission on biomedical research priorities, proposed by Senator Edward Kennedy, or controversial new authorizing legislation for the remaining nine research institutes which had been proposed by Representative Henry Waxman.

Cuts in the Defense Department's proposed research programme could set back the growth of ties between the military and universities that have been developing over the past four years, according to Pentagon officials, who warned that in particular proposed new programmes for the Department of the Army may have to be cut back.

Nor will the Defense Department be receiving the hoped-for funds to construct a new production facility for binary chemical weapons. This was deleted by members of the Senate from next year's appropriations bill, on the grounds that if the United States is to resume chemical weapons production, this should be a presidential not a congressional decision.

David Dickson

\section{Nuclear safety}

\section{European hazards}

\section{Brussels}

European nuclear power stations are not as vulnerable to operational errors as the one involved in the accident at Three Mile Island, but there is plenty of room for improvement in safety measures in nuclear power stations in the European Economic Community. This conclusion comes from a report submitted to the European Commission's Interdepartmental Coordinating Committee on Nuclear Safety (CCNS). Many of the report's proposals are disputed by the committee in an accompanying reply.

The report comes from a four-man group set up by the European Commission after the Three Mile Island incident. The members of the group were H. Dunster, Deputy Director General of the UK Health and Safety Executive, Professor Latzko of the Technische Hogeschool Delft, Professor Smidt of the Institut für Reaktor Technic der Universität Karlsrühe, and $\mathrm{Mr}$
S. Villani, Director General of the community's Joint Research Centre.

Conditions similar to those which led to the Three Mile Island accident have occurred on several occasions in Europe the report criticizes the fact that these went almost unnoticed, and calls for a data bank recording all abnormal events in European nuclear power stations.

The siting of nuclear power stations is becoming increasingly politically sensitive in Europe. The report stresses that siting has only a limited part to play in protecting the population, but that there should be a consistent approach among member states to siting nuclear plants, especially in areas close to national borders.

The group also considers that more should be done to minimize the effects of any accidents that may occur: the Commission should study the emergency procedures operating in the various member states, there should be a review of the emergency plans made by the power station operating organizations before they are licenced to operate, and more attention should be given to ways of keeping the public informed in the event of an accident.

The European Commission is criticized for not responding rapidly enough to changing nuclear research needs, for setting up cumbersome committees, and for providing those committees with inadequate technical and administrative services.

According to the Interdepartmental Coordinating Committee, many of the recommendations in the report actually tie in with actions already taken by the Commission, or actions already under consideration. But the rather half-hearted attitude towards nuclear power expressed in the report is not welcomed by the committee. The report says: "no amount of care will totally eliminate the risks of this (nuclear), or any other sort of energy .... (but) ... we are finally led to the belief that nuclear sources should continue to play a significant part in the supply of Europe's energy."

Jasper Becker

\section{Fast reactors}

\section{Low morale}

Staff morale may be as much a threat to the British fast reactor programme as the prospect of a public inquiry on the project. The latest sign of this is the resignation of Mr Jack Moore, coordinator of the fast reactor programme at the UK Atomic Energy Authority (UKAEA), at the end of the year. Mr Moore, who is 57, is leaving to take up a post with Motor Columbus engineering consultants in Switzerland. $\mathrm{He}$ said earlier this week that at UKAEA he was unlikely to see his work of the past seven years come to fruition before his retirement.

Mr Moore's resignation highlights two potential problems for the staffing policy of the fast reactor team. Although no other senior staff are reported to be leaving, further delay in a commitment to build a fast reactor may prompt others to go. The second problem is that of the age structure of the design team. Although the UKAEA has been expanding the team by bringing in young people, previous recruitment policies have left a noticeable dearth of people in their forties. When the senior staff retire or leave, their posts will have to be filled by much younger people.

A government statement on the commercial demonstration fast reactor has been expected since the summer. Sir John Hill, chairman of the authority until the end of the year, submitted a proposal to the government a year ago. Mr Moore expects that the government will respond shortly but that it will not make a final decision at this stage. One complication is that the government has not yet responded to the French proposal that Britain should by into commercial exploitation of Super-Phénix.

Meanwhile, the Nuclear Power Company is nearing the completion of a detailed design study, which Mr Moore claims will be superior to current French and Russian designs. The UKAEA would like to submit it to the Central Electricity Generating Board and potential reactor manufacturers so that a site could be chosen and a total project proposal put to the government.

Judy Redfearn

\section{Satellite communications}

\section{Free for all ahead?}

\section{Washington}

While the future of US remote-sensing satellites remains entangled in controversy (see Nature 14 August), the use of telecommunications satellites is poised for a dramatic expansion.

The Federal Communications Commission (FCC) in Washington has given permission for the launching of 20 new domestic communications satellites, which are likely to increase the capacity of the present system by a factor of four by the mid-1980s.

At least one newspaper company is discussing plans for a nationwide system of locally-produced newspapers linked by satellite, while the Communications Satellite Corporation (Comsat), which owns three of the nine communications satellites at present in orbit, has proposed starting a four-satellite system beaming television programmes directly to private homes within the next few years.

FCC approval for the authorization of the new satellite launches was given unanimously, part of what commission chairman Charles Ferris described as an "open-entry policy" to provide satellite capacity to all who want it.

A separate report prepared by commission staff, for example, has recommended that direct-broadcast satellite television services should be subject to the minimum of regulation, in 